\begin{tabular}{lll}
\hline & Yönetim, Ekonomi, Edebiyat, & JOMELIPS - Journal of Management \\
Review Article & $\begin{array}{l}\text { İlami ve Politik Bilimler } \\
\text { Dergisi,6(1):169-196 }\end{array}$ & $\begin{array}{l}\text { Economics Literature Islamic and } \\
\text { Political Sciences }\end{array}$ \\
Araştırma Makalesi & 30 Haziran/June, 2021 & e-ISSN :2547-9512 \\
DOI: $\mathbf{1 0 . 2 4 0 1 3 / j o m e l i p s . 8 3 1 6 2 1}$ & . & \\
\hline
\end{tabular}

\title{
SPECULATIONS ON PANENTHEISM IN LITERATURE, SINLESS \\ SINNERS AND DEMONIC GOOD ANGELS IN MIDNIGHT'S \\ CHILDREN AND LORD OF THE FLIES
}

\section{Hacer GÖZEN*}

\section{Timucin Bugra EDMAN}

\author{
Olga KARAMALAK
}

\section{Sercan ARISOY}

\begin{abstract}
This study applies an interdisciplinary and comparative approach to the selected works through panentheistic philosophy to visualize the abstract expressions and perception of theology and philosophy on panentheism using concrete and representational expressions of the selected novels. In the dystopian work Lord of the Flies by William Golding, this study benefits the limitless opportunities fiction offers to unveil the problem of evil and goes beyond the boundaries of the teachings, experiences and social norms the human world. The dystopian fiction Lord of the Flies, which portrays the inner and subconscious conflict between good and evil within individuals, is scrutinized from a panentheistic perspective to question the existence of evil. Midnight's Children by Salman Rushdie, as a genre of magic realism and historiographic metafiction, will enlighten the study to reveal the conflicts between destruction and creation to clarify the problem of evil which is ambiguous from a panenthestic view.
\end{abstract}

Keywords: Panentheistic philosophy, problem of evil, god, Midnight's Children, Lord of the Flies, panentheism in Russian philosophy. 


\section{EDEBIYYATTA PANENTEIZM ÜZERİNE MÜLAHAZALAR, GECEYARISI ÇOCUKLARI VE SİNEKLERINN EFENDİSI'NDE GÜNAHSIZ GÜNAHKÂRLAR VE ŞEYTANI İYİ MELEKLER}

Öz

$\mathrm{Bu}$ çalışma, panenteizmdeki din ve felsefenin soyut ifadelerini ve bakış açısını görselleştirmek amacıyla, seçilen romanları somut ve kavramsal ifadelerini kullanarak, disiplinlerarası ve karşılaştırmalı bir yaklaşımla panenteistik felsefe açısından ele alır. $\mathrm{Bu}$ çalışma, William Golding'in distopyası Sineklerin Efendisi romanında şeytan sorunsalını açığa çıkarmak amacıyla kurgusal anlatıların sunduğu sınırsız imkânlardan faydalanır ve insan dünyasındaki öğretilerin, deneyimlerin ve sosyal normların sınırlarını aşar. Bireylerde iyi ve kötü arasındaki bilinçdışı içsel çatışmaları sergileyen distopik kurgu Sineklerin Efendisi, bu çalışmada şeytanın varlığını sorgulamak amacıyla panenteistik bakış açısıyla irdelenir. Muğlak olan şeytan sorunsalını netleştirmek için, yok etmek ve yaratmak arasındaki çatışmaları açığa çıkarmak amacıyla, büyülü gerçekçilik ve historiyografik üstkurmaca türünde bir roman olan Salman Rushdie'nin Geceyarısı Çocukları, panentestik bakış açısıyla bu çalışmaya ışık tutar.

Anahtar Sözcükler: Panenteistik felsefe, Şeytan sorunsalı, Tanrı, Geceyarısı Çocukları, Sineklerin Efendisi, Rus felsefesinde Panenteizm.

\section{INTRODUCTION}

Most religions compose a belief that God (Gods/Goddesses) created the world and the universe. This belief leads people to show their respect to nature itself, and this respect even exists in pseudo-religions created by humans. This belief means that there is always an authority who is above everything. While defining the existence and meaning of God, some philosophers equates God with Nature while others state that God is above Nature but stays ever-ready in the nature, which indicates Nature itself and every entity in nature is the reflection of God and God's existence. For example, according to Plato, everything we see is the reflection of God (Pappas, 2017). In this regard, Panentheism presents us a possibility of modern religions. 
Before interpreting the selected novels, it is important to understand the concept of panetheism, its meaning and interpretations. In the nineteenth century, the term 'panentheism' was created by the German philosopher Karl Krause (1781-1832) in 1829:

The term 'panentheism' is derived from the Greek words meaning 'everything' (pan), 'in' (en), and 'God' (theos). Whereas pantheists hold that the totality of the universe and God are identical without remainder, panentheists think that, although the totality of the universe is, in some sense, 'in' God, the existence of God also, in some way, transcends the totality of the universe. Bradley Shavit Artson suggests that 'as good a definition of panentheism ... as we are likely to find' is given in the Jewish Midrash, in which it is said that 'God is the place of the world, but the world is not God's place' (Artson 2014, 24, quoting Bereshit Rabbah 68:9). (Burns, 2018, p. 6-7)

In the Shorter Oxford English Dictionary, panentheism is defined as "the belief or doctrine that God includes and interpenetrates the universe while being more than it"; and is "a particular view, or family of views, of the relationship between God (the divine) and the world (nature, the cosmos, the universe)" (qtd. in Main, 2017, p. 1104). Shortly after Krause, von Schelling and Hegel, in the deliberations about Spinoza's pantheism, maintained the philosophy of panentheism, which became subject matter for contemporary Christian theologians, historians of Western esotericism, process philosophers, scholars of non-Christian religious traditions, philosophers such as Charles Hartshorne and William Reese, and Alfred North Whitehead, "scholars of non-Christian religious traditions, and researchers attempting to find adequate ways of theorizing the well-testified 'rogue phenomena' of psi and mysticism" (Kelly, Crabtree, Marshall ctd. In Main, 2017, p. 1124). Furthermore, in their studies, Loriliai Biernacki and Philip Clayton exposed panentheistic discourses situated in Christianity, Judaism, and Islam, Tibetan Buddhism, Jainism, Hinduism, and Confucianism (Main, 2017, p. 1108).

Panentheism is an open-ended philosophy as philosophers, scholars and theologists assert many different categories, perspectives and distinctions on the definition or the frame of panentheism (See Attfield, 2019; Baltzly 2010, Bracken, 2014; Burns, 2018; Caresse, 2010; Cooper 2006; Hartshorne, 1948; Main, 2017; Mikael 2018). "As a concept, panentheism has deep roots. Yet, despite some prominent advocates, it has not truly flourished until relatively recently" (Peterson, 2001, p. 396), and "is not stable in itself. The little word 'in' is the hinge of it all. There may be as many panentheisms as there are 
ways of qualifying the world's being 'in god"' (Clayton and Peacocke qtd. in Bracken, 2015, p. 207).

The recent standpoints on panentheism emerge from the contrastive investigation of ethical systems in the Hebrew and Egyptian/Babylonian theology by Assmann who is a pioneer among contemporary philosophers and theologists. One of the points on the identity of God in panentheism that proposes "the world as the embodiment of a soul-like god and of god as a soul animating the world" has a correlation in Egyptian religion (Assmann 2008 quoted in Main, 2017, p. 1103). Jung's studies, archetypal theories and definitions of good and evil, are also revealed as panentheistic discourses (Jung cited in in Main, 2017, p. 1109).

In panentheism, first, "God contains the world, yet is also more than the world. Accordingly, the world is (in some sense) 'in God"”, and second, "[a]s contained 'in God', the world not only derives its existence from God, but also returns to God, while preserving the characteristics of being a creature. The relations between God and the world are (in some sense) bilateral" (Gregersen quoted in Attfield, 2019, p. 167). "The physical matter of the world exists" "within God' who is infinite and "holds the world within himself in some sense"; the physical matter of the world has "no independent existence apart from God" (Clayton quoted in Attfield, 2019, p. 173); "while the universe is wholly dependent on God, God could exist independently of the actual world and of any other world" (Attfield, 2019, p. 168). In other words, the beginning of God is not based on any force. God takes power from himself and the cosmos is the sub-creation of God. God exists before and after the cosmos. Nevertheless, God is both inside and outside the cosmos. In this manner, it might be interpreted that a human who inhabits the world is not totally independent of the existence of God. On the contrary, to the finite existence/power of human, God has infinite existence, power and potential; he is not in a limited body or mind with limited power as a human is; "God does not have a humanlike brain, and therefore cannot have thoughts that are constrained, as ours are, by the limitations of the body of which the brain is a part"; that is why none of the created, no part of God in the cosmos can affect his existence or power:

'The Creator, through his Spirit, $d w e l l s$ in his creation as a whole, and in every individual created being, by virtue of his Spirit holding them together and keeping them in life. The 
inner secret of creation is the indwelling of God. ... Absolute space means the direct presence of God in the whole material world and in every individual thing within it'; 'The motivation of the doctrine of divine omnipresence, then, is not to pretend that all things are God, but to locate all things within the divine presence, which is the only source of all existing things. ... If space is God's space, then the world is not 'outside' him but by definition within him'; [in this regard,] everything can be understood as existing 'in God', and also in which God can be understood as present and dwelling in everything. (Moltmann and Clayton quoted in Attfield, 2019, p. 174)

In this part, here come the questions related to the problem of evil in Panentheistic perspective. Gregersen asks: “Are all things really united with God? Is small-mindedness, miserliness, hatred, torture, terror, war?" (quoted in Attfield, 2019, p. 17). If God is the creator and is responsible for the power of humans to transcend themselves and engender new constructions through their free will, which is either for good or evil, and if God embodies the cosmos, universe, world and human in himself, why does he allow such evil? Is the creation of evil compatible with a loving God? In short, panenthestic philosophy has the stance that God is infinite and independent, and his existence is free of any other existences; he compounds the existence of other universes, cosmos and the world with humankind; which means, the finite cosmos, world, nature and human stand in the body of infinite God. That is to say, God's nature of infinity comprises the finite as he encompasses humans who are finite. So, why did God transmit part of his power in a limited form to humans? In this study, we will compose three answers to interpret the problem of evil in Lord of the Flies and Midnight's Children from a panentheistic perspective. The first response is 'free will', which a person is gifted with; the second stance is the reflections of God through opposite qualities; the third statement is the evolution and advancement of human nature/character.

\section{A COMPARATIVE STUDY OF PANENTHEISM IN RUSSIAN PHILOSOPHY AND CULTURE}

Russian Orthodox culture contains a tendency of pantheistic worldview philosophy where God equals Nature. The adoption of Christianity and its development in the Russian culture maintains of the pagan deification of Nature. This feature of Russian Orthodoxy and Russian culture was well described by Trubetskoy (1995, pp. 295-301, 370-380, 398404), who claimed that Russian icon-painting of the 14-16th centuries clearly shows a 
desire for rapprochement between the heavenly, divine world and the earthly, human world; this is what distinguishes Russian icon painting from its Byzantine type. Especially clearly relevant features are manifested in the work of Andrei Rublev. Rublev's icons express the unity of God and earthly reality, divine light fills the entire space of the image and means the presence of God is in every element of being; at the same time, it is a man who is able to fully absorb the divine light and unite with God, thereby revealing his or her divine perfection.

In the first half of the 19th century, when independent philosophical thought was emerging in Russia, pantheistic tendencies became determinative due to the enormous influence of Schelling. The first independent system of Russian philosophy, the system of Chaadayev, clearly shows signs of pantheism. For Chaadayev (1991), God is the power of unity, acting throughout the world and leading the world to a state of absolute unity. Chaadayev calls this unity "great everything" and understands it as the absolute goal of the world process. With this concept, Chaadayev began the tradition of the philosophy of total unity, which can be understood as an original version of pantheism, characteristic of Russian thought.

According to Chaadayev (1991), the main force opposing the divine power and introducing dissonance and fragmentation into being is the individual, arbitrary freedom of a person; in this regard, Chaadayev argues that the main task of a human is to overcome his or her individual freedom, leading to merging with the divine power and subordinating himself or herself to it.

A similar concept can be found in the philosophy of Vladimir Solovyov (1988), his pantheistic ideas are clearly influenced by the ideas of Schelling, Hegel and Spinoza. Describing the world process, Solovyov comes to the conclusion that his goal is the state of all-unity, that is, the transition of the world to a perfect, divine state in which the world connects with God.

Pantheistic features can be traced in the philosophical worldview of Dostoevsky. Marya Lebyadkina in the novel "Demons" (Dostoevsky, 1995) says that the Mother of God is "raw earth", i.e. identical to earthly nature. With even greater clarity, the pantheistic tendency is present in the statements of the old man Zosima in the novel "The Brothers Karamazov" (Dostoevsky, 2002), for example, he says that "life is paradise, and we are 
all in paradise", we just don't know this, but if we knew, it would become paradise all over the world. In Dostoevsky's views, pantheistic motives are combined with personalism, with the recognition of the absolute metaphysical significance of every human person.

In the 20th century Semyon Frank moved from the philosophy of pantheism to panentheism where Being is regarded as the Absolute All-unity. According to Frank, the God-Absolute, which is the existential foundation of the world, receives the features of a superpersonal (and not impersonal) Absolute, which means that the connection to it by a human person must be understood as a mystical act that takes a person beyond his or her personal limitations. God cannot be equal to singular beings, however, his participation in a person and the world leads to the fact that they "in a limited way themselves become divine (Frank 1998, p. 49). Nothing exists outside of God, but all the world in its wholeness is not identical to it. Frank wrote "All-in-one cannot 'crack' so much so as to fall apart into pieces ... it is only broken to our human aspect" (Frank, 1972, p. 518). In the aspect of the Divine, it remains eternally integral, since its cracks "immediately fill and become positive, being from the Primary Self, and the Truth merges in an absolutely harmonious All-in-one" (Frank, 1972, p. 518-519).

He considers evil as something, which a human should be responsible for since God created a divine and perfect World and God is not a source of evil. Thus, evil is not part of this God-Absolute and it is not part of Being. Evil cannot surpass Good. According to Losskiy, the reason that "Frank cannot isolate God from evil and does not dare to include evil in God" is precisely in the fact that he exaggerates the unity between God and all the universe (Losskij, 2011, p. 375). Frank's understanding of evil is complicated but a person takes responsibility. A person falls into evil, he or she submits to the forces of evil that take him or her as a prisoner. That is why, a person participating in evil must feel the responsibility and guilt for the evil that is happening (Frank, 2007).

\section{A COMPARATIVE STUDY OF PANENTHEISTIC PHILOSOPHY AND SELECTED WORKS MIDNIGHT'S CHILDREN AND LORD OF THE FLIES ON THE PROBLEM OF EVIL}

This research embodies abstract reasoning on panentheism in a reified comprehension in the fictional secondary worlds of the selected novels to find out solutions to the problem 
of evil in primary human world (the physical world humans live in/ the limits of experiences, knowledge or teachings imposed in that world) as Tolkien clarifies. Fantasy works propose humans to go beyond the limits of their primary worlds and have limitless imagination or perception to find solutions for problems from the limitless perspective proposed in fictional works (Tolkien, 2016). Rushdie's novel, Midnight's Children, is about the challenge of evil and good. Rushdie blends the fight with magical realism and historical fiction to create a "secondary world" where readers can take the journey of the characters and go beyond the enforced limits of their "primary world" (Tolkien, 2016). The novel does not present or prescribe the state of goodness as the only option. On the contrary, it combines good and evil in the plot structure, which depicts both notions as powers granted humankind which is also a subject matter in panentheism. The novel reveals good and evil given to humankind by the Creator, which are means of selfrealization, and fit their free will. Similar to panentheist philosophy, in the novel, humans act using the power of good or evil, and face the consequences of their choices. Through the novel, Rushdie portrays the connection of God with his creations through the proposed power of good and evil, which also has common ground in panentheism.

Moreover, the analysis of cultural phenomenon through isolated settings is useful for readers to dissociate themselves from the subject of the study. As Postmodernism is known to deconstruct the social norms of society, isolation is a popular means for writers to have readers criticize themselves from an outside perspective. In works that explore the morals of society, protagonists may function as the translator between the reader and the setting. The protagonist can also be the channel to represent the emotional reactions of the readers. It is important for protagonists to embody a wider range of emotions for readers with different personalities to sympathise with them. Lord of the Flies is a postmodern novel that features a nurturing island as the embodiment of God and the complex power struggle and violence of children as the existence of evil in human nature. The novels Midnight's Children and Lord of the Flies are interpreted from a panentheist perspective in the next sections to reveal the problem of evil, and give possible explanations for the existence and role of evil. 


\section{A response to the problem of evil: Free will}

The first response to the problem of evil is 'free will' given to humankind where evil functions as a human choice; "[ $\mathrm{t}]$ he creator, operating through evolution and through human history, might be expected to provide free persons with opportunities for moral choices. A good God might credibly grant freedom of choice to conscious agents, for the sake of their being able freely to choose to do his/her will," (Attfield, 2019, p. 176); "[i]f the origin of everything is a living energy, then we can access this energy and reunite with this living energy or soul, God. ...God's ecstasy is the Creation of a Self-Creating Universe" (Bruteau quoted in Schmitt, 2018, p. 38). It is God, who created and determined everything in the cosmos; yet, humans are left free to change.

God created the cosmos and left the rest to the will of humans; people can develop and change it, or destroy it. That means God creates humans in a neutral embryo like the notion encompassing humans with the power of both evil and good and lets them complete their own creation and evolution in either way in the sense of identical and moral value in the form of human nature and character. This is the power denoted to humans, to complete their own being. Nevertheless, no evil that people can do is beyond God's power, but only [it] can be beyond his purpose. Violence, wars and slaughter in human history reveals that reality. However, we need to clarify that the power given by God to humans to evolve or enhance themselves does not make them god-like because it is a finite power designed by an infinite God who has endless power to recreate endlessly. In Midnight's Children, on the eve of the Independence of Pakistan, from the night of August 14 to August 15 1947, 1,001 unusual children were born:

\footnotetext{
...no less than one thousand and one children were born within the frontiers of the infant sovereign state of India. ...the nature of these children, every one of whom was, through some freak of biology, or perhaps owing to some preternatural power of the moment, or just conceivably by sheer coincidence, endowed with features, talents or faculties which can only be described as miraculous. (Rushdie, 1980, p. 196).
}

The miracle here was the gifted children who were armored with such power to change the creatures or environment they were in. 1,001 miraculous incidents take place at that night, and these miraculous children can act freely to choose what they want to become, or do whatever they wish to do. The proposed power and choice by God for the children 
to create or destroy depicted in the novel are reflected through panentheistic philosophy. As is in panentheism, God is the sole power and the sole creator who has the sole control over the cosmos, to create, to destroy, or to change it. Yet, he bestows his power of creation and destruction on the children, which might be interpreted as the practice of godhood for the children which enables them to act like gods.

In Lord of the Flies, the island where the story takes place is a reflection of the omnipotent power and the forgiveness of God. It is depicted in such a way to emphasize its purity: “...a great platform of pink granite thrust up uncompromisingly through forest and terrace and sand and lagoon to make a raised jetty four feet high. The top of this was covered with a thin layer of soil and coarse grass and shaded with young palm trees" (Golding, 2001, p. 5). The island is nurturing, forgiving and a potential ground where children can practise their free will. Like God, the island can exist independently. In panentheistic study, the island is the provider of free will and the example of pure goodness. Pureness comes from the fact that island remains the only entity that is not corrupted by free will. Throughout the story, the majority of children involved in harmful acts, especially during the killing of Simon which reminds us of the Biblical first bloodshed in the story of Cain and Abel. However, the island remains as the provider of blessings or the endower it has been since the start of the novel. Unchanged nature of the island is one of the indicators of omnipotence. The island is a shelter amidst the war. Due to the choices made by evil children (evil as the conscious act of indulging in evil acts), the harmonious depiction of the island contrasts heavily with the state the island is in at the end of the book. However, the change the island experiences does not originate from its self-creating system. The island's passive state is an indicator of the reflection of God's qualities; it is because while preserving the power of destruction, the island remains passive and forgiving like God, enabling children to practise their free will.

Upon their arrival, the children are wearing school uniforms. Their attire functions as a representation of civilization. Unfortunately, the social conditioning and the uniforms themselves decay gradually and lose their relevance. Since there is no adult presence on the island, the children are free to do whatever they like. The only drive that influences their actions are basic human needs, the rest are the cause of their practice of free will. 
This idea of freedom plays a huge role in interpreting the reasons for the children's actions.

\section{A response to the problem of evil: Opposite reflections of qualities}

As a second stance, 'power', which is given to humans by God to change, advance or influence, either for good or evil, will be analyzed as a response to the problem of evil. Moltmann summarizes the notion of panentheism, "God acts in and through the activities of his creatures; ...created beings act out of the divine potencies and into a divine environment [which is interpreted as free will in the previous section]; the activity of created beings is made possible by the divine patience; the presence of God in the world is the space free for the liberty of created beings. ... The God who is present in every part of the world and in every part of it, is the creative Spirit"; God has infinite power as a creator and creates a cosmos in which he "makes creatures make themselves" (quoted in Attfield, 2019, p. 175).

In other words, God creates other beings/humankind and gives them the potential and power to create themselves. In this regard, humans possess power, which emerges from or reflects some qualities of God to create and influence the world. However, human power is from God, endued and limited by God, which means 'world is dependent on God' but 'not vice-versa'. "God could exist without a world, and therefore creates freely" (Attfield, 2019, p. 172); nevertheless, the existence of the world and humans who are placed in the world is contingent on God's choice, and "the world is an expression of God's will and omnipresence" (Clayton quoted in Attfield, 2019, p. 173).

God is not dependent on any creatures that he created and empowered. It is because God determined each law of nature at the beginning before the creation of the universe, and later, designated limited power to his creatures to set a self-creative and organizing system in a limited time, which is equal to the existence of the creatures' lives. Yet, God still holds limitless power, endless time and endless potential to recreate, and can recreate the destruction of his creation endlessly. In this perspective, the self-creating system in panentheism might be interpreted as the power devoted to chance, recreate, influence or affect (which is a common discourse in unitarian basis, Jews, Muslims and Unitarians) (see Attfield, 2019, p. 175). Being created with a gift, which is power from God, cannot be interpreted as a god-like being. Burns proposes that in panentheism philosophy, a 
human does not have the urge to be 'god-like' since a human is already in God and has part of God's power (Burns, 2019).

Through the above mentioned philosophy of panentheism it might be advocated that the creation of evil also has another function which is to reflect the opposite qualities of goodness to make all qualities clear and comprehensible, as qualities or features are grasped through their opposites. However, God does not have any opposite or opponent in the cosmos, but his qualities have. That is why humans cannot comprehend God without the degree of his qualities. At this point, God gives humans some limited form of his own qualities, one of which is power. God and his power are eternal and limitless, and he created humans finite with limited power to enable them to grasp the endless cycle of the cosmos, which is far beyond their possession.

God created evil as the opposite reflection of his goodness. For instance, humans understand the power of God through their own weakness; humans understand the degree of God's knowledge with the degree of their own illiteracy; grasp the infiniteness of God with their transience. Humankind, who is always in need, understands that God is not in need of anything because limited qualities are characteristic of created ones, not of the creator. He lets his creation, humankind, taste a modicum of his absolute endless and eternal qualities; make humans comprehend his endless and eternal qualities and power.

To make it clear we might say that, for example, to understand the degree of temperature, we need to know hot/cold; the degree of light is perceived with the degree of dark; the degree of meal's flavor changes according to our level of hunger/satiety; we understand how important a generous donation is when we are deprived of it. It is the degree of brutality we encounter that enables us to understand the importance of mercy for creatures and human beings. The nature of creatures' weakness or the state of being weak teaches us the degree of power; we learn God's mercy and grace through the savagery and mercilessness of beings. How much humans need or seek mercy, justice and grace being weak and defenseless, they acquire the importance of those in that degree. Humans grasp the degree of justice in the degree of injustice. Humans might be happy when they avenge the oppressed against the oppressor, and the oppressed ones' gratefulness makes them happy as being the ones who have experienced this oppression. We understand the worth of health in illness; and the worth of freedom in imprisonment; and the value of love in 
the degree of hate. Humankind grasps the degree of God's qualities and his creation and cosmos, through evil, which is also a creation by God, in God.

In this regard, if every quality can be known by its opposite, it might be proposed that God created evil and indwelled it in the cosmos as the opposite reflections of God's unattainable quality of goodness, mercy, grace and grandeur. God knows the truth about everything in the universe; but humans can only know the truth as much as the potential of their body and mind, which are limited. If humans did not know evil, they would not know beauty, justice or mercy. When humans compare their own power with God's endless system, they admit that their own power is as weak as they are in the cosmos. In other words, humans realize that the power that dwells in the world and generates it, in the same manner, indwells humans. At this point, humans appreciate that all existing power in the cosmos, even their own power, is from and belongs to God. The notion of opposites, which are sensible in their degrees, is the same in the existence of evil.

In Midnight's Children, at the beginning of the creation of the 1,001 children, the children chose to be with Saleem Sinai because of his ability to create a conference in his mind and connect to other children no matter where they are, which is significance of God's quality, who is always in connection with his creatures, and is reflected in Saleem: "By sunrise, I had discovered that the voices could be controlled-I was a radio receiver, and could turn the volume down or up; I could select individual voices; I could even, by an effort of will; switch off my newly-discovered inner ear" (Rushdie, 1980, p. 162).

Despite the fact that the amongst 1,001 children there are a great variety of abilities, Shiva and Saleem were the body and the mind of Midnight's Children: "So among the midnight children were infants with powers of transmutation, flight, prophecy and wizardry... but two of us were born on the stroke of midnight. Saleem and Shiva, Shiva and Saleem, nose and knees and knees and nose... to Shiva, the hour had given the gifts of war (of Rama, who could draw the undrawable bow; of Arjuna and Bhima; the ancient prowess of Kurus and Pandavas united, unstoppably, in him!)... and to me, the greatest talent of all - the ability to look into the hearts and minds of men" (Rushdie, 1980, p. 200). They both had the greatest power equal in degree, which was to lead, construct, create, upgrade their social constructions, or enhance their people in nature. Their power was a reflection of God's power as in panentheist philosophy, which is to acquire God and the degree of his 
qualities. Due to their positions in this society, both Shiva and Saleem were eligible to become leaders but they went into different directions by their own choice; one became God, and the other evil. The reflections of God in their nature transform them into different characters; this is the significance of free will for self-creation, either as good or evil.

Saleem adds: "Midnight's children!... From Kerala, a boy who had the ability of stepping into mirrors and re-emerging through any reflective surface in the land-through lakes and (with greater difficulty) the polished metal bodies of automobiles... and a Goanese girl with the gift of multiplying fish... and children with powers of transformation: a werewolf from the Nilgiri Hills..." (Rushdie, 1980, p. 198). Each child is created with unique qualities in a degree, which are correlated with each other and require unity and harmony, as they are limited and restricted in a sense. When Midnight's Children gather together in Saleem's mind, they all accept Saleem as their leader and act in unity and harmony as the parts of the power in a body, as the reflections of God who created the cosmos, the world and humankind, in a body sharing a system of power in a degree which is to act in harmony to enhance.

In Lord of the Flies, it is possible to observe how the children reflect the qualities of God in a micro-level dimension. In the early actions of the children, reasons for certain violent actions can be excused or found necessary. However, with each act of violence, the dosage increases. Multiple choices indicate the presence of free will in the actions of the children. Characters like Jack and Roger in contrast to Simon and Piggy display how choices affect people's reasoning and actions. While some seek to destroy, others seek civilized methods and focus on establishing a functional social order. Piggy thinks of a functional way to tell the time: "I've been thinking," he said, "about a clock. We could make a sundial. We could put a stick in the sand, and then..." (Golding, 2001, p. 54); Piggy's practical logic is contrasted with Ralph's childish exaggeration of offering to build a plane, a TV set and even a steam engine, further emphasizing the maturity of Piggy's logic and reasoning. In terms of civilization and the functionality of good will, Piggy is the most important character in the novel. His spectacles are symbolic. They are used to start fire to create smoke to attract passing ships. Furthermore, he plans to use sticks for a sundial by utilizing the power of the sun (the power of God) and the physics 
of shadows. Piggy functions as a reflection of God's qualities; the power to use the sun. As explained in panentheistic philosophy, Piggy is gifted with a part of God's power; the ability to use the sun's power. Not only is fire the element that played a huge role in the progression of humanity, but it is also a way for the boys to benefit from God's power, the sun. Piggy is the symbol of reason, science, order and the fragile balance of life. Therefore, he is gifted with the ability to use God's power to start a fire. Yet, when the power given to Piggy is stolen and corrupted by the other boys, the fire functions as a destructive power, burning the nurturing environment of the island. Piggy's chubby body and the problems with his eyesight represent how fragile the intellectual harmony can be. This fragile balance is represented by others' perception of Piggy: "Piggy was a bore; his fat, his asthma and his matter-of-fact ideas were dull, but there was always a little pleasure to be got out of pulling his leg, even if one did it by accident" (Golding, 2001, p. 54). He is certainly not a boy that can maintain his intellectual sanity in a survival-of-the-fittest oriented structure. As the death of Piggy marks the end of intellectual and scientific reasoning on the island, the boys finally become aware of the evil taking over: "Ralph wept for the end of innocence, the darkness of man's heart, and the fall through the air of the true, wise friend called Piggy" (Golding, 2001, p. 182). The social structure that is heavily focused on physical strength and control over good will is no place to live in. It is impossible to maintain any environment where the goodness is swallowed by ruthless savagery.

Simon's conversation with the lord of flies indicates the main point of the novel. The persisting source of fear on the island has been the potential of a beast before the exchange with the pig's head. The young children, especially, were haunted with the nightmares of such a fearful entity. During the hallucination, Simon is told that the beast resides in all of them: "Fancy thinking the Beast was something you could hunt and kill!... You knew, didn't you? I'm part of you?' (Golding, 2001, p. 128). The very fact that young children have nightmares about the beast indicates the existence of evil within their psyche. As Simon investigates the source of fear, he realizes that the corpse of the parachutist is inanimate, and the corpse is not a beast. He rushes to let the others know. His arrival is the precise moment when he encounters the beasts. Boys covered in paint, chasing after him making barbaric noises, killing Simon. The level of violence on the island is gradually increasing. So far, only pigs were hunted on the island, which could have been 
excused as an act of survival. However, the death of Simon was caused by murderous intent. Jack's reign on the island is one based on bloodlust and dictatorship: "At once the crowd surged after it, poured down the rock, leapt on to the beast, screamed, struck, bit, tore" (Golding, 2001, p. 136). Jack's tribe is a society of its own albeit a kind that is not nurturing or beneficial for anyone. The death of Simon could be a misunderstanding. However, the misunderstanding would have been easily avoided if boys had used reason before instinct.

\section{A response to the problem of evil: Self-creating beings}

As a third response to the problem of evil from the panentheistic perspective, it might be inferred that evil has a parasite-like function which leads human nature to evolve and advance to be a powerful and challenging one. Michael Ruse answers the question of evil with the view of 'fallen angels' who lead other creatures or humans into a cancer-like ill nature, into evil (Attfield, 2019, p. 177), and which is for humans to challenge. Reichenbach and Southgate (qtd. in Attfield, 2019, p. 177) explain the reason why God lets evil into the cosmos: God empowered creatures/humans with an open system in the cosmos in which humans use their free will for either good or evil, and which is to flourish and advance their character and being. The opposite reflections of goodness in evil and the created beauty in cosmos, which are the reflections of God's goodness and beauty, are all for humans, who are equipped and furnished with mind, free will, and power. Humans, who are between evil and good, are to choose to enhance themselves for good or evil. Human choices and actions will advance them in the degree of either good or evil; "a good God might credibly allow a cognitive distance between the perspective of human agents and their attainment of a clear vision of the path of salvation, for the sake of the development of their characters" (Hick cited in Attfield, 2019, p. 176).

According to Moltmann, God created the universe as an open and 'self-transcendent' system which engenders new constructions and evolutions which have inconceivable finality, proposing new potentials and 'a diversity of communicating' (cited in Attfield, 2019, p. 175). In this stance, it is not coincidence that God empowered the creatures in a self-transcendent system; on the contrary, God created such an empowered system on purpose. Moltmann calls the system of the universe an 'open system' but Peacocke opposes that and calls it 'a closed mechanism.' In this notion, we might compose both 
stances and state that God created an 'open system' which is evolving and self-creating. Furthermore, the system is predetermined and limited by God who has limitless power over the creatures; in this regard, the system is " a closed mechanism' operating according to laws and with boundary conditions both prescribed 'at the beginning' and identified with a temporal act of creation by God'. Creation is rather to be understood as continual, not least through the creative action of natural processes, which are also acts of the creator" (quoted in Attfield, 2019, p. 175).

Humans take actions and evolve depending on their own choices, and God is also active in his human creations and on the ground and in the cosmos he proposed to human service for their self-transcendency. God, the 'higher-order system', gives humans 'free will' for their 'self-agency' to advance their mind, which is essential for their personhood and moral value. This proposed free will is not freedom-from, but freedom-to, the creator (Cranwell, 2010, p. 219); the free will here is to return to God (Attfield, 2019, p. 175); as a man dwells in God, and is a part of God.

Burn (Burns, 2019) clarifies the problem of evil in the panentheistic view by the definitions of 'God the Good' and 'God the World'. 'God the World' implies that every existing being is 'in' God; but not 'of' God. Therefore, evil is 'in' God; but not 'of' God. 'God the Good' implies that God is 'the universal concept of Goodness'; God, in the notion of 'God the Good', leads the beings to act in goodness, and increase and flourish goodness in the world, which is parallel to Plato's Form of the Good in the elucidation by Iris Murdoch. Burn also refers to Kant's discussion of evil to clarifythe problem of evil in an equivalent sense in which he says that "there may, indeed, be an 'evil principle', but that humankind should follow 'the leadership of the good principle' to seek 'freedom from the dominion of evil"'; evil, which dwells in the world, engenders suffering, violence and destruction, and is "like parasites in the body of God"; the only condition for overcoming it and recovering is to live "under the influence of God the Good" (Burns, 2019, pp. 7-17).

Burns adds, "[t]hus, God the World is responsible for our existence, whereas God the Good is the aspect of divinity which promotes flourishing. ...the believer is then responsible for participating in divine action by attempting to change the world for the better. Just as the human body sends white cells to fight an infection, so human persons, 
guided by God the Good, can become the metaphorical white cells which work to heal the ills of the world" (Burns, 2019, pp. 7-17). In this sense, evil exists in the cosmos, which is a horrendous and cancer-like, disease spreading the white cell of God the World; yet, a human is not alone to face the evil; humankind is armored with the inspiration of God the Good to overcome it. This does imply that human is active in cosmos to advance, change or influence it. God gives humans the power to generate existing beings, either to spread evil or advance goodness, which depends on human choice, free will, and moral value. Humans are obliged to challenge evil using their gifted power and free will. If humans are gifted with power to create, develop or advance goodness, which is reflection of God, they are obliged to do it, and are to take action. If humans are gifted with mind and reasoning, they are obliged to be conscious of, and scrutinize the relationship or difference between good and evil.

The antagonist of Midnight's Children, Shiva, who was named after the Hindu God of Destruction, (Rushdie, 1980, p. 126-127), combines his free will and power that is given on the same night with the other 1,000 children to hold the supreme power and take the control of other children. In his childhood, he had only his father to take care of him. Nevertheless, his environment, social life and the other children caused the emergence of the bad temper in his nature day by day; as, while they were growing up, other kids teased Shiva because of his pale and weak nature (Rushdie, 1980, p. 127). All the problematic social constructions and the environment he grew up in and the problems he experienced drew him to breaking point where he chose evil in the notion of self-destruction by the means of the power God proposed which was being gifted as self-creation or selfdestruction. At first sight, it seems Shiva is under the burden of his name; yet, he chose to destroy not only himself but everything that stood against him. His power from God turns into revenge, which is evil. His will to get revenge on the God who created him in that world, led him into a state in which he acted as if he gained endless and invincible power challenging against everything he encountered, even the creator. Shiva desired to turn his luck and take control of Midnight's Children.

The bad and evil temper of Shiva does not date back to his birth and is not the creation of God: “...if you had asked my father (even him, despite all that happened!) who his son was, nothing on earth would have induced him to point in the direction of the 
accordionist's knock-kneed, unwashed boy. Even though he would grow up, this Shiva, to be something of a hero" (Rushdie, 1980, p. 117); on the contrary, his evil nature is his self-creation. Instead of being a hero of goodness for the children, he chose to be a villain. Although Saleem was one of the most powerful of the children, his power did not transform him into an evil being. In fact, being gifted, Saleem acted like a prophet among the children and delivered their messages to each other. This gift enhanced his good temper and his spirit, and made him more ambitious to help the children, which is the state of self-creation and social construction for goodness. This helped him improve his ability and he started collecting information about the children so that he can help the others easily: "I contented myself with discovering, one by one, the secrets of the fabulous beings who had suddenly arrived in my mental field of vision, collecting them ravenously..." (Rushdie, 1980, p. 198).

In Lord of the Flies, the reflection of panentheist self-creating philosophy either in good or evil is observed in children significantly. The children alone on the isolated island are now to create a system and evolve as individuals. They will not be the same as once they were under the protection of their parents. When they were with their parents, they were deprived of power. Quite the reverse, on the island, they possess the power to create for themselves the new world they are in. Roger is the most problematic among the characters due to the sheer evil potential in his character. His action against the twins is an early glimpse of the evil tingling inside him as well as a foreshadowing of what is going to happen to Piggy: "Roger took up a small stone and flung it between the twins, aiming to miss. They started and Sam only just kept his footing. Some source of power began to pulse in Roger's body" (Golding, 2001, p. 158). The intention of harming someone and deliberately missing the shot emphasizes the struggle between evil potential and social conditioning. The reason Roger misses the shot is because of social conditioning. Roger's upbringing stopped him from putting his evil ideas into action, as shown in the uniform. Yet, the freedom provided by the environment of the island gave him the incentive he needed to experiment with his essence. As Roger grows with evil, the size of the stones he throws gets bigger and eventually kills Piggy. In Roger's case, the growth of the stones used can be compared to the evil sprouting inside him, which is an example of selfcreating philosophy in panentheism. 
Like Roger, Jack flinches and misses the shot when he is hunting for food for the first time. His prey flees and he promises himself that the next time he will be more enduring: "I was choosing a place," said Jack: "I was just waiting for a moment to decide where to stab him" (Golding, 2001, p. 23). With each counter, the reader witnesses a gradual increase in violence and evil within the children. Both Roger and Jack have evil as parasite within them. Both characters were between evil and good, tamed by social conditioning. Their hesitation to act in an evil way is due to their adaptation to society. However, their active choices reinforce the evil parasite, which ultimately takes control of them. The explanation of 'higher-order system' in this article sheds light on the importance of social conditioning. All the boys were conditioned to behave properly in the sense of not indulging in activities that can hurt other beings meaninglessly, directly or indirectly.

Another example of self-creating philosophy in panentheism is Jack. Social conditioning is not impenetrable. Jack paints his face with clay and charcoal because he thinks his pinkish face is not suitable for hunting. A pinkish face can be indicative of pureness: “... the mask was a thing on its own, behind which Jack hid, liberated from shame and selfconsciousness" (Golding, 2001, p. 53). The paint enables Jack to create a new persona to be able to take evil choices. As explained in Jung's Persona theory (Jung, 1966), Jack's savage persona helps him disassociate himself from the social norms he had been taught, unleashing the potential of evil within.

Creating a system or a structure in the world order is another example of the power offered to humans. The concept of social order can be observed in the various rules the children establish on the island. They gather around at the sound of conch shell, establishing a democratic social structure and appoint a leader for the group. They create subunits to focus on duties for the good of the whole. However, as they spend more time on the island, most rip off their civilized attire and gradually shift towards savagery. Duties are not carried out properly, and they destroy the freedom of speech by destroying the conch shell. The boundaries of human's teaching and social norms do not bind them from that point onward. The gradual change of the children while they were transforming or shifting into evil is of the essence in a panentheistic view because the shift from goodness into 
evil occurs through upgrading processes, which are the experiences of many choices through free will; they freely and willingly choose to act in an evil way.

\section{Can evil harm God's authority or creations?}

Burns asks, "If evils are actual or potential parasites in the body of God", why does God permit his own body to be infiltrated in this way? Can God be all-good while existing evil? If man/evil has power to engender or evolve the universe, can God still be independent enough to be the world's creator? (Burns, 2019, p. 19). Through the regard of the God-human-evil relation in panentheistic view, we might say that God grants power to a human from his own endless supremacy to advance his nature in the world or cosmos. Therefore, the power of a human is limited by God and God's power is endless; so that, any man's destructive action can be recreated or renewed by God endlessly; which means that neither man's nor evil's destructive actions may be influential on the cosmos when it is contrasted with the infinite power and creation of God. It is because a finite power cannot destroy or influence an infinite power, which has the endless knowledge and power to create beings endlessly. That is to say man's or evil's power, which are limited and finite, are insubstantial in contrast to God's infinite and limitless power. God gives human power, which is limited and finite, and God is in communication with humans. A human's power can neither reduce God's infinite power nor damage it.

Let us suppose metaphorically that the creation of nature, human and evil as a computer game, and God as the programmer of the software of this game, who can create infinite kinds of software endlessly. In this supposition, God puts humans into the world of the computer game, teaches people the technical information of the game to enable them to use the system in this simulated world, and gives them free will and power to change this fictional system using the information. Humans can improve, have fun in harmony, or destroy everything created in the game. This power and choice are up to humans, and they are finite. When the time comes, when 'the clock strikes 12', in the form of death, humans will lose all their power. Human power will turn into 'a pumpkin'. In this sense, can people's actions in this fictional game influence or damage the creator of the software or his game? Or, can people create a lasting and endless impact on him or the game? Which evil action in this game can create lasting and endless destruction? In a similar sense, can any evil action in the cosmos have any impact on eternal God, who has endless 
power to recreate endlessly? When we consider the size of the universe and the galaxies which seems to be endless as we have not discovered the whole yet, we can see that a man or evil in man, in fact, has no effect enough to move even a leaf in the game. When the game is over and a human exits, when people's power ends, they will face the gains or loss of their actions performed in the game. The gains or loss here would be nothing more than their own self, and their own nothingness.

For another assumption, let us consider the light and energy of the sun; just as a person who receives fire from the sun as from a candle either to brighten or burn the environment. In this regard, humankind can neither diminish the light/fire of the sun, nor harm the sun; he or she cannot declare himself or herself a sun as well. That means, when the powers are compared in degree, neither the evil nor goodness of a man can influence God; they are just symbolic. People are gifted with evil and good. The results of his or her responsibilities depend on a person's degree of moral value. Humans are responsible for each of their actions, which are limited and in a limited world. When we consider the God-human-evil relation, we may see that God gives part of his power to both humans and evil. The power which is given to humans has two functions; to reconstruct or destroy. Yet, the power which evil possesses is only to destroy.

Everything in the universe is within the knowledge and power of God, as he is the one who created all. God creates; human acts, either for good or evil. Gregerson interprets the notion of free will: "[T] he creation and the redemption of the world are regarded as the self-realization of the divine life. In the end, the Spirit will work to reconcile the created and alienated world with eternal being. At the same time, evil, supposedly a necessary outcome of the emergence of humanity, becomes absorbed by God" (cited in Attfield, 2019, p. 172).

In Midnight's Children, Shiva's limited power and gift bring him into a state in which he perceives himself and his power above every other creature, and he also perceives himself as the sole limitless power to own or destroy the rest: "Yah, little rich boy: one rule. Everybody does what I say or I squeeze the shit outta them with my knees!” (Rushdie, 1980, pp. 220-221). Saleem reminds Shiva that they are there for a purpose, they are not a God, can be defeated and are nothing without each other as they were created in such a form which requires unity and harmony to act for goodness by the means of their gifted 
power: “...but at that point I found a measure of courage and told Shiva, 'You can't run the Conference; without me, they won't even be able to listen to you!'” (Rushdie, 1980, pp. 220-221). This may be a declaration of war but they both knew that they cannot be a God on their own. Saleem has midnight's children's support; but, Shiva is one of the most powerful among them. As individuals, even being gifted, none of them can be a God; they can only be part of God.

Saleem Sinai tells us that his grandfather was a Muslim until the day he hit his nose while praying and it started bleeding: "... and at that moment, as he brushed diamonds contemptuously from his lashes, he resolved never again to kiss earth for any god or man." (Rushdie, 1980, p. 4). His rejection or challenge to the authority of God, and his declaration of independence does not bring him the level of authority, as his power or independence in the cosmos and in its system is limited and finite in contrast to God's infinite power.

In Lord of the Flies, Simon's and parachutist's bodies drift away with the soothing waves along the beach. The contrast between human pyromania and the eternally rejuvenating nature of the island symbolizes how the existence of good and evil are depicted in this article. While the evil is absorbed by God through nature, embracing the dead bodies and giving them everlasting shelter, evil is a lingering presence in minds, looking for a moment of weakness.

With the removal of the parachutist's body, the physical representation of the beast is gone, and the evil shows itself in Jack's tribe. Unlike in Simon's case, Piggy's death bears no excuse. The sheer sadism of Roger is fully unleashed. The destruction of the conch symbolizes the extinction of any functional social order. After experiencing the empowering sensation of being able to overpower others, the seed of evil quickly evolves and takes control of the action of children.

Jack sets the whole island on fire to force Ralph out of his hiding place. The tactic itself is close to atomic bomb attacks in human history. The cause of action for the destruction of nature is purely personal on Jack's part. When children are compared with adults in war, the presence of evil does not only reside within the naïve and fragile nature of children, but it continues to exist throughout the lifespan of individuals. Therefore, it is a constant matter of choice to be good and remain good or be evil. 
Golding's island might be interpreted as a micro-level dimension of the world as the creation of God who dwells in the human and offers the power of self-creation to perceive God's power, which is omnipotent, as the macro-level. In other words, on the island, the children are able to create their own personality and society. They take responsibility to create or destroy a social system, or respect or destroy others, which is psychologically or mentally the state of godhood, or an experience of feeling themselves as God. It might be interpreted as a micro-level dimension of godhood. For example, with an atomic bomb, Hiroshima was destroyed. A generation was devastated by it. It is the similar state observed in Jack's action, when he sets the whole island on fire. Through the perception of the micro-level dimension of God's power, it is clear that the destruction of the island cannot destroy God's authority in any way as it is a small part of God's creation when it is compared to the whole universe, and as the island has a renewable natural system as well. None of evil action can destroy God's authority or power. The destroyed thing in this island is the moment that is offered to the children for their self-creation, not the whole time of the island in an enduring system. They destroyed the moment they lived in. When the moment they exist on the island ends, the island renews itself and a new 'moment' starts. Through this perspective, the only destroyed thing is the opportunity for self-creation offered to humanity. It is a state of self-destruction. Little children on a little island with little power display the brunt violence and total destruction challenging the creation of others and themselves. As in a testing laboratory, in the micro-level dimension, in Golding's island, the human might be in the micro-level dimension of God's power being tested as well. The human might be dwelling in God's island with the evil that dwells in humans.

\section{CONCLUSION}

To expose the problem of evil and the inner and subconscious conflicts of humans between good and evil, the selected dystopian works Lord of the Flies by William Golding and Midnight's Children by Salman Rushdie are analysed through a comparative panentheistic perspective. Through the analysis of the panentheistic standpoint it is revealed that God is in a permanent connection and unity with humans. Any behavior, any choice, any decision, any question or answer, and any step taken by a human is a 
communication between God and a human. By giving them an opportunity to choose and take decisions, God empowers people with free will.

In conclusion, God dwelled humans in a perfect system and served them power and free will to advance themselves and nature to complete their embryo like state. God proposes human life, which is in an embryo like state, and offers them many abilities and opportunities to grow their own state, and shape it in accordance with their own decisions willingly and freely. Even, humans have chances to shift their state into good or evil at any time or at any level in accordance with their own choices. God leaves humans to their own decisions for what and in what ways to use the forces served in nature or the cosmos. Humankind can use the energy from the sun, wind, animals or anything in the cosmos either for good or ill, to destroy or construct; to complete their own evolution and character. Humans can transform the energy into life or a destructive weapon, as they did in the past with the atomic bomb. Humans can evolve the venom of a snake into an antidote or a deadly weapon. In a way, God serves power from his own. With reasoning, mind and free will, humankind can use that power to maintain or dispose of the life balance in the universe.

It seems that a human is advanced in a degree more than other beings from the standpoint of the balance of power in the world. When compared to other living things and nature, humankind possesses a superpower in a way, by which they can change things into a destructive system, and can attempt to destroy an entire race, as in Hitler's genocidal system in Europe, or in the colonial systems in Africa. On the other hand, a human becomes more independent through his or her self and nature. This independence is either from God or to God. The more you develop your nature and self, the better you integrate into the perfectly created system of the universe in harmony, which means human's independence to God brings him into harmony with the cosmos. Development does not bring mismatch, but harmony through the system in the universe, which is a higher order level. On the other hand, independence from God brings the destruction of the nature and the self, it is because the self and nature are the parts of the cosmos which requires harmony.

The system of the world/nature is open to humans to change, reconstruct, or deconstruct. Even though it is limited, a human's power enables him or her to make changes in the 
universe; yet, no power of the devil can harm God. Every existing thing is from God's infinite power and his endless creation. Then, if God is eternal, no finite power can damage or influence him. God, who has endless knowledge and endless power to create, can recreate the destroyed ones endlessly. No finite force can harm God who has the power to create endlessly. Regardless of the outcome of all these choices, the tendency of the human being is always to throw the responsibility to someone else and to put the burden(s) of any problem on the shoulders of God. Since avoidance of responsibility relates to the fear of the consequences of actions, one thinks that by evading this responsibility, it is possible to have one's sins forgiven. In fact, once the responsibility is accepted, the fact is that good deeds and bad deeds become the reflections of the person. Just as William Shakespeare said, "Hell is empty, and all the devils are here" (Shakespeare, 2002, line 2015). Because we are the good and the bad ones and all our actions create a circle that depends on causality in which God is outside of this actionreaction circle, which enables a person to maintain freewill, but God still watches us very closely.

\section{BIBLIOGRAPHY}

Attfield, R. (2019). Panentheisms, Creation and Evil. Open Theology, 5, 166-181. https://doi.org/10.1515/opth-2019-0012

Baltzly, D. (2010). Is Plato's Timaeus Panentheistic?. Sophia 49, 193-215, Springer Science+Business Media B.V. 2010. DOI 10.1007/s11841-010-0170-z

Bracken, J. A. (2014). Panentheism: Hierarchically Ordered Systems of Existence and Activity. In The World in the Trinity: Open-Ended Systems in Science and Religion, 65-90. Minneapolis: Augsburg Fortress, Publishers. Accessed March 27, 2020. www.jstor.org/stable/j.ctt9m0vjs.7

Bracken, J. A. (2015). Panentheism and the Classical God-World Relationship: A Systems-Oriented Approach. American Journal of Theology \& Philosophy. 36(3), 207-25. Accessed March 27, 2020. doi:10.5406/amerjtheophil.36.3.0207

Burns, E. D. (2018). Patching Plantinga's ontological argument by making the Murdoch move. In T. Dougherty \& J. Walls (Eds.), The plantinga project: Two dozen (or so) theistic arguments (pp. 123-136). Oxford: Oxford University Press. 
Burns, E. D. (2019). How to prove the existence of God: an argument for conjoined panentheism. International Journal for Philosophy of Religion, 85, 5-21 https://doi.org/10.1007/s11153-018-9690-1

Chaadayev, P. Ja. (1991). Filosoficheskie pis'ma. Pis'mo pjatoe (Philosophical letters. Letter 5). Polnoe sobranie sochinenij i izbrannye pis'ma, $v 2$ T. Full collected essays and selected letters in 2 Volumes. M.: Rimis. V. 1, pp. 377- 389.

Cooper, J. (2006). Panentheism: The Other God of the Philosophers-From Plato to the Present. Nottingham, UK: Apollos.

Cranwell, C. (2010). Embracing Thanatos-in-Eros: Evolutionary Ecology and Panentheism. Springer, 49, 271-283. DOI 10.1007/s11841-010-0177-5

Dostoevsky, F. (1995). Demons. (Trans. Pevear and Volokhonsky) New York: Vintage Classics.

Dostoevsky, F. (2002). The Brothers Karamazov. (Transl. Pevear and Volokhonsky). (12th edition) New York: Farrar, Straus and Giroux.

Frank, S. L. (1972). Ontologicheskoe dokazatel'stvo bytija Boga (Ontological Proof of God's existence). Retrieved from http://lib.ru/HRISTIAN/FRANK_S_L/bytie.txt

Frank, S. L. (2007). Nepostizhimoe. Ontologicheskoe vvedenie v filosofiju (Incomprehensible. Ontological introduction to philosophy). M.: AST.

Frank, S.L. (1998). Svet vo t'me (Light in the darkness) Retrieved from http://azbyka.ru/otechnik/

Golding, W. (2001). Lord of the Flies. New York: Penguin Books.

Hartshorne, C. (1948). The Divine Relativity: A Social Concept of God. New Haven: Yale Univ. Press.

Jung, C. G. (1966). Two Essays on Analytical Psychology. The Collected Works of C.G. Jung, (Vol. 7, Part 1, 2nd ed). Princeton University Press, Princeton, NJ, Bollingen Series XX.

Losskij, N. O. (2011). Istorija russkoj filosofii (History of Russian Philosophy). M.: Akademicheskij proekt: Triksta. 
Main, R. (2017). The Many Faces of Panentheism, Panentheism and the Undoing of Disenchantment. Zygon, 52(4), December, 1098-1122.

Pappas, N. (2017). Plato's Aesthetics. The Stanford Encyclopedia of Philosophy (Fall Edition), Edward N. Zalta (ed.), URL = $<$ https://plato.stanford.edu/archives/fall2017/entries/plato-aesthetics/>.

Peterson, G. R. (2001). Whither Panentheism?. Zygon, 36(3), September. ISSN 05912385.

Rushdie, S. (1980). Midnight's Children. New York: Random House (electronic).

Schmitt, J. F. (2018). Natural Inclusionality, Indigenous Wisdom, and the Reality of Nature. Hu Arenas 1, 37-55 https://doi.org/10.1007/s42087-018-0008-8 Received: 10 January 2018 /Revised: 25 January 2018 /Accepted: 31 January 2018 / (Springer International Publishing AG, Springer Nature 2018).

Shakespeare, W. (2002). The Tempest, The New Cambridge Shakespeare. (Edited by David Lindley). New York: Cambridge University Press.

Solovyov, V.S. (1988). Kritika otvlechennyh nachal (Critics of abstract beginnings). Sochinenija v 2 T. (Essays in 2 V). M.: Orthodox Library V. 1, 586-590, 691-745.

Stenmark, M. (2018). Panentheism and its neighbors. online: 27 October 2018, International Journal for Philosophy of Religion (2019) 85:23-41 https://doi.org/10.1007/s11153-018-9687-9

Tolkien, J.R.R. (n.d.). On Fairy Stories. accessed January 2016, http://www.rivendellcommunity.org/Formation/Tolkien_On_Fairy_Stories.pdf Trubetskoy, E.N. (1995). Mirosozercanie V.S. Solov'jova (Soloviev's Worldview). V I. M. 